\title{
Ecosystem engineering by burrowing crabs increases cordgrass mortality caused by stem-boring insects
}

\author{
Alejandro D. Canepuccia ${ }^{1,2, *}$, Juan Alberti ${ }^{1,2}$, Pedro Daleo $^{1,2}$, Jesus Pascual $^{1}$, \\ Juan L. Farina ${ }^{3}$, Oscar O. Iribarne ${ }^{1,2}$ \\ ${ }^{1}$ Laboratorio de Ecología, Universidad Nacional de Mar del Plata, CC 573 Correo Central, B7600WAG, Mar del Plata, \\ Argentina \\ ${ }^{2}$ Consejo Nacional de Investigaciones Científicas y Técnicas (CONICET), Buenos Aires, Argentina \\ ${ }^{3}$ Museo de Ciencias Naturales Lorenzo Scaglia, Área Entomología, Mar del Plata, Argentina
}

\begin{abstract}
Some studies have shown that the balance between top-down and bottom-up processes is context dependent, but few have tested how biotic interactions can affect this balance. We quantified the attack frequencies by the stem borer moth Haimbachia sp. nov. on the cordgrasses Spartina densiflora and $S$. alterniflora in 5 marshes of the southwestern Atlantic coastline, located between $36^{\circ} \mathrm{S}$ and $41^{\circ} \mathrm{S}$. We examined whether ecosystem engineering by burrowing crabs Neohelice (Chasmagnathus) granulata, which improves plant performance, increases herbivory incidence by moths. The results show that moths attack an important proportion of Spartina spp. stems ( $4 \%$ to $26 \%$ ). Moth attack frequencies were higher on low elevation than on high elevation marsh plants, probably due to variations in plant performance across the physical stress gradient. Within marshes, burrowing crab densities and moth attack frequencies were positively correlated, suggesting that ecosystem engineering by crabs may increase moth attacks. Field experiments confirmed this prediction and suggest that the effect of crabs on moth attacks may be driven by nutrient availability. Our results show that stem-boring herbivores can cause significant plant mortality in Spartina spp. marshes, and that ecosystem engineering by burrowing crabs increases this effect. Thus, in this system, biotic factors that improve plant performance lead to an increase in herbivory control.
\end{abstract}

KEY WORDS: Bottom-up control · Haimbachia sp. nov. · Herbivory $\cdot$ Neohelice (Chasmagnathus) granulata $\cdot$ Spartina spp. $\cdot$ Top-down control $\cdot$ Salt marsh

\section{INTRODUCTION}

Ecologists have long debated how resource availability (bottom-up effects) and/or consumer pressure (top-down effects) shape natural plant communities (e.g. Teal 1962, Power 1992, Valiela et al. 2000, Bertness et al. 2008). It is now widely accepted that plant production can be influenced by feedbacks associated with these 2 effects (e.g. Walker \& Jones 2001) and that top-down forces can increase with the quality of the environment (e.g. Menge \& Sutherland 1976, Prezler \&
Boecklen 1996, Bertness et al. 2008, Sala et al. 2008). However, ecosystems are complex, and the identification of interactions between regulating forces becomes far more difficult when we attempt to understand how the balance between these opposing effects varies due to indirect interactions (Power 1992, Strong 1992). Such information is crucial to understand the factors that modulate productivity, and their effects on the systems.

Salt marshes are among the most productive systems (Mitsch \& Gosselink 2001). In these environments, pri- 
mary productivity is mainly controlled by bottom-up process (physical stress or nutrients) that regulate trophic relationships (Odum \& Smalley 1959, Teal 1962, Valiela et al. 2000). However, there is also evidence that consumers may influence marsh productivity (Pennings et al. 1998, Silliman \& Zieman 2001, Jefferies et al. 2006, Sala et al. 2008) and that their effects vary with physical stress gradients across tidal elevation (e.g. Moon \& Stiling 2002, Rand 2002, Alberti et al. 2007) and increase in marshes with enhanced nutrient availability (Jefferies 1997, Silliman \& Zieman 2001, Bertness et al. 2008, Sala et al. 2008). Certain organisms can directly and/or indirectly control nutrient availability to other organisms (i.e. ecosystem engineers, Jones et al. 1994), leading to bottom-up control. Nevertheless, little is known on how top-down control of salt marsh plant productivity varies due to the indirect effects of ecosystem engineering species.

The salt marshes occurring between southern Brazil $\left(32^{\circ} \mathrm{S}\right)$ and northern Argentinean Patagonia $\left(42^{\circ} \mathrm{S}\right)$ are dominated by the cordgrasses Spartina densiflora and S. alterniflora (see Isacch et al. 2006) and by the burrowing crab Neohelice granulata (species formerly known as Chasmagnathus granulatus, see Sakai et al. 2006 for taxonomic revision). This burrowing crab is an efficient ecosystem engineer (sensu Jones et al. 1994, see Gutierrez et al. 2006, Daleo et al. 2007, Fanjul et al. 2007). In marshes, crabs excavate and maintain semipermanent open burrows (e.g. Spivak et al. 1994) that can extend up to $1 \mathrm{~m}$ into the sediment, with surface openings of up to $10 \mathrm{~cm}$ diameter and with a density of up to 60 burrows $\mathrm{m}^{-2}$ (Iribarne et al. 1997, Botto et al. 2005). Burrow maintenance results in sediment removal of up to $2.5 \mathrm{~kg} \mathrm{~m}^{-2} \mathrm{~d}^{-1}$ (Iribarne et al. 1997), which increases soil nitrification-denitrification ratios due to enhanced soil oxygenation (Botto et al. 2005, Gutierrez et al. 2006, Fanjul et al. 2007). These activities can boost plant productivity by facilitating mycorrhizal formation (Daleo et al. 2007) and by increasing nutrient availability (Fanjul et al. 2008). These positive effects of crabs on plants could be transferred through the food web to other species. In fact, by increasing the density of reproductive stems, crabs positively affect granivorous species (Canepuccia et al. 2008), which increase their use of areas with higher densities of reproductive stems (marsh birds: Cardoni et al. 2007, rodents: Canepuccia et al. 2008). Thus, we may expect a similar process with herbivorous species. Given that most marshes are nitrogen-limited (Valiela \& Teal 1974, Adam 1993), and that plants of higher quality as food item are more attractive to several herbivores (Moon \& Stiling 2002), we hypothesized that the positive effect of burrowing crabs on plants will also indirectly favor the establishment of plant consumers, intensifying herbivore pressure.
Stem-boring insects are common marsh herbivores that can have important impacts upon their host plants (e.g. Stiling \& Strong 1983, 1984, White et al. 2005). The stem borer moth Haimbachia sp. nov. (Crambidae: Crambinae) is commonly found in SW Atlantic Spartina densiflora and $S$. alterniflora marshes. The larvae overwinter inside grass stems, and when the adult moth emerges in spring and summer, it makes a characteristic hole through the stem (Fig. 1). The overwintering larvae feed on more than half of the central tissue of the stem, eventually killing the stem as a result of the damage (A. Canepuccia pers. obs.; Fig. 1). Thus, this moth can potentially have an important negative effect on Spartina spp. Stem borer larvae are restricted in their mobility (see Rathcke 1976, Stiling \& Strong 1983); thus, mature females usually oviposit on highquality hosts to maximize the fitness of their brood (Mayhew 1997, Moravie et al. 2006). In this context, we predict that higher nutrient availability due to burrowing crab activities (Bertness 1985, Fanjul et al. 2008) will promote attacks of Haimbachia sp. nov on Spartina spp. plants. Hence, this multi-species scenario (plant: Spartina spp., crab: Neohelice granulata, and moth: Haimbachia sp. nov.) may provide a model system to investigate how the intensity of herbivore pressure varies with other biotic drivers, and if this is a widespread pattern across some of the most extensive SW Atlantic coastal marshes. Thus, we examined: (1) the attack patterns on stems of Spartina spp. produced by moth larvae in salt marshes across marsh tidal height and throughout several SW Atlantic coastal marshes, (2) whether positive effects of $N$. granulata on $S$. densiflora indirectly increase herbivory pressure of Haimbachia sp. nov. on S. densiflora, and (3) given that the underlying mechanism could involve nutrient availability, whether increasing nutrient supply (bottom-up effect) could lead to increased herbivory pressure from moth larvae feeding on salt marsh plants.
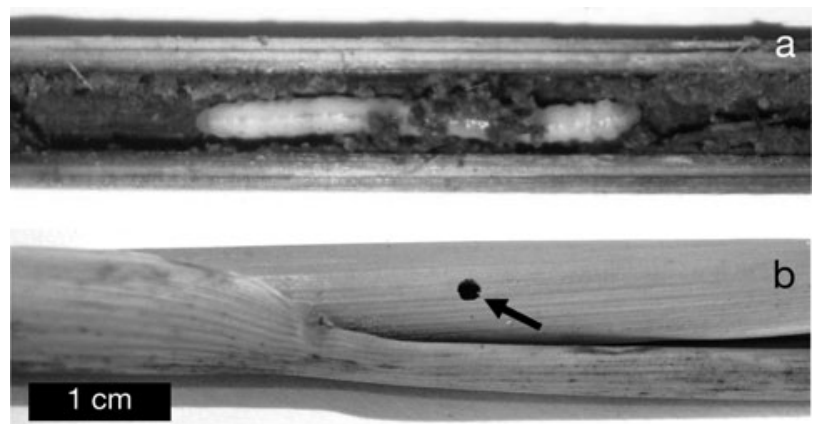

Fig. 1. Spartina alterniflora and Haimbachia sp. nov. (a) Longitudinal section of an attacked stem, with a moth larva inside, showing the area consumed by the larva. (b) The hole (arrow) produced by the moth when it emerges as an adult 


\section{MATERIALS AND METHODS}

Study area. The study was carried out in 5 Argentinean marshes located between the mouth of the La Plata River estuary (Ria de San Clemente, $36^{\circ} 22^{\prime} \mathrm{S}$ ) and the northern part of Patagonia (San Antonio Bay, $40^{\circ} 84^{\prime} \mathrm{S}$ ) including some of the most extensive SW Atlantic coastal marshes (see Isacch et al. 2006; Fig. 2). Studied marshes are located at San Clemente (36 22' S), Mar Chiquita coastal lagoon (37 32' S), Bahía Blanca $\left(38^{\circ} 41^{\prime} \mathrm{S}\right)$, Bahía Anegada $\left(39^{\circ} 48^{\prime} \mathrm{S}\right)$, and Bahía San Antonio (4084'S, Fig. 2). The cord grasses Spartina alterniflora and $S$. densiflora and the perennial glasswort Sarcocornia perennis (formerly known as Salicornia ambigua) cover $70 \%$ of these marshes (Isacch et al. 2006). The Mar Chiquita coastal lagoon is dominated by $S$. densiflora, while the other sites are inhabited by both cordgrasses. Given logistic and economic constraints, we performed the experiments to evaluate the effects of burrowing crabs on stem borer moth-Spartina spp. interactions with $S$. densiflora at the San Clemente and Mar Chiquita marshes (Fig. 2). In the studied marshes, S. alterniflora occupies sites at a lower marsh elevation than $S$. densiflora, which occurs at a wide range of intertidal elevations including the upper marsh edge (Isacch et al. 2006). Thus, for comparative reasons, we divided marshes into 4 intertidal levels according to their ele-

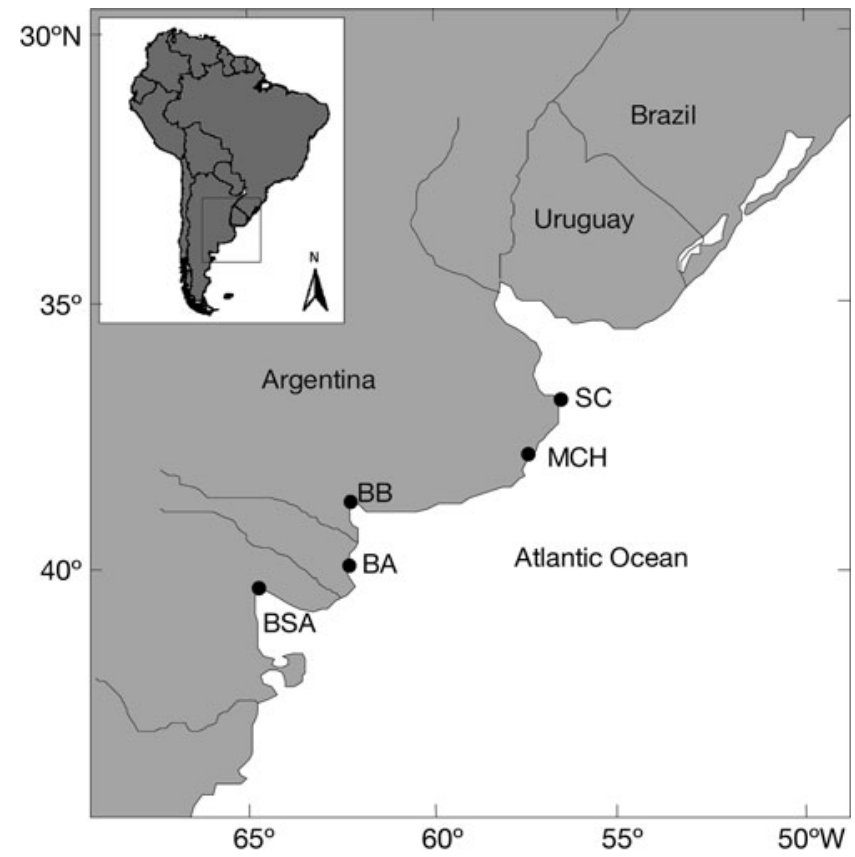

Fig. 2. Marshes sampled along the south-western Atlantic coast. SC: San Clemente, MCH: Mar Chiquita, BB: Bahía Blanca, BA: Bahía Anegada, BSA: Bahía San Antonio vation: the lowest, occupied by $S$. alternifora, and 3 upper levels occupied by $S$. densiflora (thereafter named 'high,' 'middle,' and 'low'). The lowest marsh remains under water more frequently than the middle marsh, which develops at $50 \%$ of the higher tidal altitude. High marsh flooding occurs only during the highest spring or storm-induced tides.

Attacks by stem borer moths on Spartina spp. After adult moths emerged at the end of the summer (March 2008), we sampled $S$. densiflora and $S$. alterniflora stems to estimate the attack frequency of moth larvae. Given that herbivore damage on plants often varies spatially across tidal gradients (Rand 2002, Alberti et al. 2007), we collected 10 random samples of plants (containing 30 adult stems each) at each marsh level described above for each marsh location. All stems were cut at ground level, and then were longitudinally cut and classified as attacked (stems with larvae or evidence of their activity: holes, tunnels, or sawdust, Fig. 1) and not attacked (stems without larvae or evidence of their activity). We estimated the frequencies of moths attack on $S$. densiflora and $S$. alterniflora as the ratio between the number of moth-attacked stems and the total number of stems in each sample. A Tukey test following an analysis of variance (ANOVA; Zar 1999) was used to evaluate the null hypothesis of no differences in the proportions of attacked stems between marsh elevations.

Does the effect of burrowing crabs on Spartina densiflora increase the attacks by stem borer moths? The burrows of crabs and crab activity can locally have positive effects on plant growth (Bertness 1985, Kristensen 2008; see also Daleo et al. 2007 for this crab species). We evaluated whether there was a relationship between crab density and the proportion of stems attacked by moth larvae across marsh sites. To evaluate the possible relationship between crab density and the proportion of stems attacked by moth larvae, we collected plant samples in the low marsh, where crab densities are most variable. During the summer of 2008 (after adult moths emerged), we collected 30 randomly chosen stems inside each of 50 quadrats $(0.5 \times 0.5 \mathrm{~m})$ with varying crab densities in the low $S$. densiflora zone at each study site. The proportions of attacked stems were assessed as described above. To estimate crab densities, we counted the total number of crab burrows in each plot (a good estimator of crab densities, see Iribarne et al. 1997, Bortolus \& Iribarne 1999). Correlation analysis (Zar 1999) was employed to examine the relationship between crab density and moth attack at each marsh site.

To experimentally evaluate the association between crabs and the proportion of stems attacked by moth larvae, we performed a caging experiment manipulating crab densities from February 2005 to May 2007. 
Thirty permanent cages (plastic mesh squares $1 \times 1 \times$ $0.5 \mathrm{~m}$; mesh size: $1.5 \mathrm{~cm}$, which allowed free movement of moths but excluded crabs) were deployed at an intermediate elevation at Mar Chiquita. We selected this marsh elevation because crab densities are lower than at the lower marsh level, and thus it was relatively easier to keep them from invading the exclusion treatments. It was also easier, and resulted in fewer undesired effects, to increase crab burrow density than to decrease it. We buried cages $20 \mathrm{~cm}$ into the sediment to prevent crabs from burrowing beneath them. We cut roots and rhizomes with a shovel around the perimeter of each cage to a depth of $20 \mathrm{~cm}$ to avoid resource reallocation through clonal integration. Cages were randomly assigned to 3 different treatments: (1) crab inclusion: 10 cages in which we used a corer to make 30 artificial burrows ( $4 \mathrm{~cm}$ diameter, $1 \mathrm{~m}$ deep) and included $1 \mathrm{crab}$ ( 3 to $4 \mathrm{~cm}$ carapace width) in each, i.e. 30 ind. $\mathrm{m}^{-2}$ (similar to field densities, Botto et al. 2005); (2) burrows without crabs: 10 cages with 30 artificial burrows but without adding crabs, to independently evaluate the effect of burrows; (3) full exclusion: 10 cages in which we removed crabs from natural burrows by hand and then filled the burrows with sediment from an adjacent area. Treatments were maintained weekly to ensure that every burrow was active in treatment (1), that every burrow was not active in treatment (2), and that no crab invaded treatment (3) during the study period (for similar design see Bortolus \& Iribarne 1999, Bortolus et al. 2004, Canepuccia et al. 2008). After more than 2 yr (from February 2005 to May 2007), we collected 30 random Spartina densiflora stems cage $^{-1}$ to determine the proportion of attacked stems as described above. To fit the assumption of linearity and normality, the proportion of attacked stems from the Mar Chiquita study site were square transformed (Zar 1999). A Tukey test after significant ANOVA (Zar 1999) was used to evaluate the null hypothesis of no differences between treatments in the frequency of stems attacked by moth larvae.

Does increased nutrient supply lead to an increase in herbivory pressure by stem borers? Given that burrowing organisms usually increase soil nutrients (Bertness 1985, Fanjul et al. 2007, 2008), we performed a second experiment to evaluate whether the frequency of Spartina densiflora stems attacked by moths increased with soil nutrient levels, at San Clemente and Mar Chiquita marshes from December 2005 to April 2007. Quadrats $(0.7 \times 0.7 \mathrm{~m})$ were randomly selected at the $S$. densiflora marshes of San Clemente (14) and Mar Chiquita (16). Plots were randomly assigned to 1 of 2 treatments: (1) nutrient addition ( $\mathrm{n}=7$ and 8 , respectively) and (2) control (no nutrients added; $\mathrm{n}=7$ and 8 , respectively). Nutrient addition plots received $30 \mathrm{~g}$ of fertilizer pellets containing $29 \% \mathrm{~N}, 5 \% \mathrm{P}$, and
$5 \%$ K every month (see Emery et al. 2001, Daleo et al. 2008 for similar procedures). At the end of the experiment, after adult moth emergence in summer, we randomly cut 30 stems of $S$. densiflora in each plot to determine the proportion of attacked stems. The null hypothesis of no differences in the proportion of attacked stems between treatments was evaluated with $t$-tests (1 for each site, Zar 1999).

\section{RESULTS}

\section{Attacks by stem borer moths on Spartina spp.}

Overall, the analysis of 10400 Spartina spp. stems showed that moth larvae attacks varied from 4 to $14 \%$ of $S$. alterniflora stems and between 6 and $26 \%$ of $S$. densiflora stems depending on the marsh (Fig. 2). The larvae make a characteristic hole between the second and third stem internodes for drainage of excretions and cached food (Fig. 1). At least half of each stem with larvae or pupae inside was dry, whereas stems that were alive and not attacked by moth larvae were entirely green. All attacked stems from which the larvae had already emerged as moths were completely dry. The proportion of attacked stems varied with marsh elevation. Three of the 5 marshes sampled (San Clemente, Mar Chiquita, and Bahía Blanca; Fig. 2) showed a much higher proportion of attacked stems in samples collected from the low marsh than in those collected from the high marsh (Tukey test after ANOVA, Fig. 3a). The other 2 marshes (Bahía Anegada and Bahía San Antonio) showed lower moth infection than the 3 marshes indicated above, and showed no differences between marsh elevations (Fig. 3a).

\section{Does the effect of burrowing crabs on Spartina densiflora increase attacks by stem borer moths?}

There were positive relationships between crab densities and the proportion of attacked stems in all $S$. densiflora marshes (Fig. 3b). The experiment manipulating crab densities confirmed that stem damage is related to the presence of crabs. Cages with crabs and burrows had, on average, more than twice the proportion of attacked stems of $S$. densiflora than cages from which crabs and their burrows were excluded (Tukey test, $\mathrm{p}<0.05$ after ANOVA, $F_{2,27}=4.67, \mathrm{p}=0.018$, Fig. 4). Instead, the proportion of attacked stems in cages with only burrows (without crabs) was not different from the attack proportion observed in cages with crabs and burrows, and in cages without crabs and burrows (Tukey test, p > 0.05, Fig. 4). 


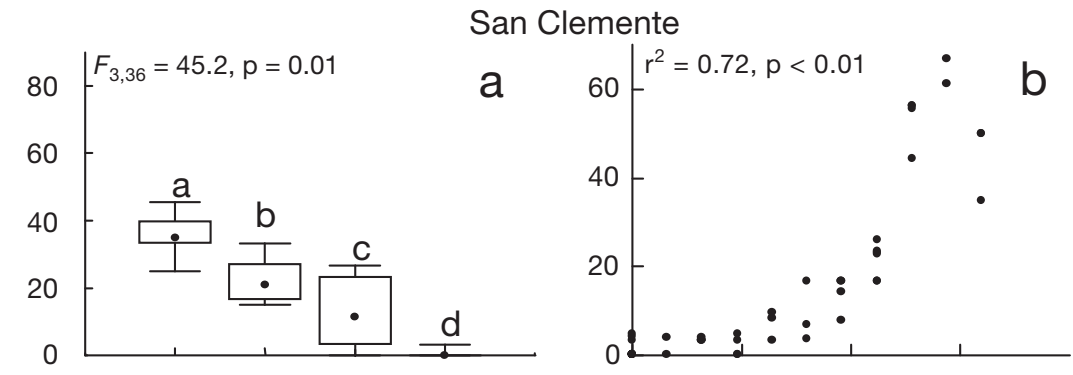

Mar Chiquita
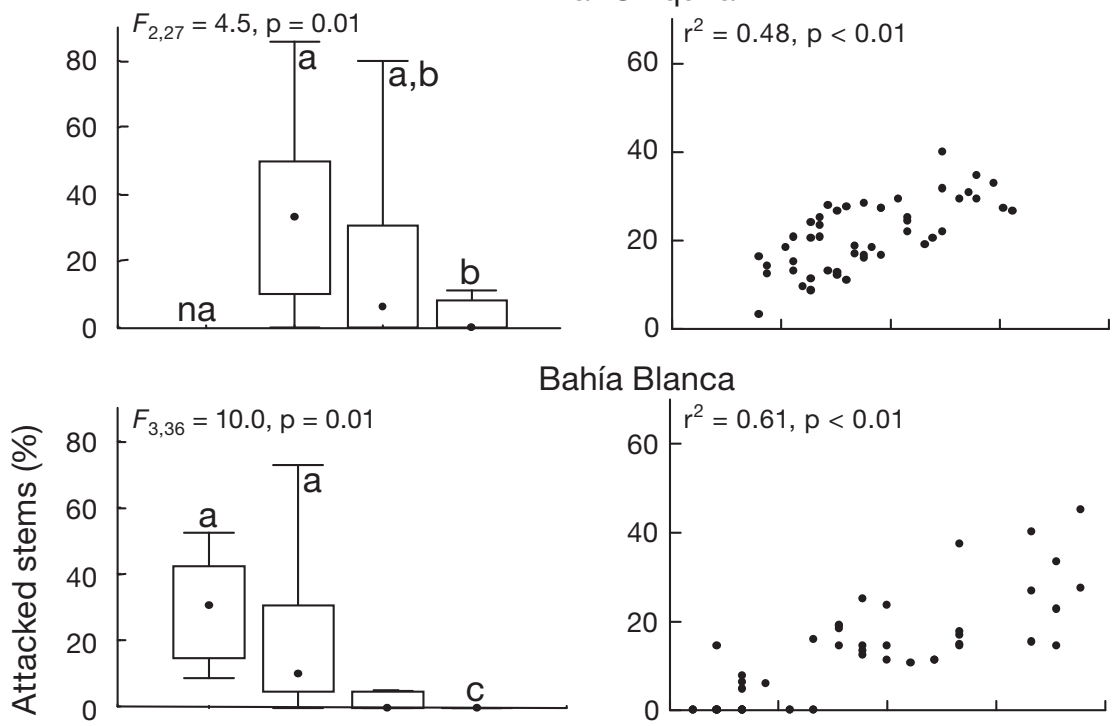

Bahía Blanca

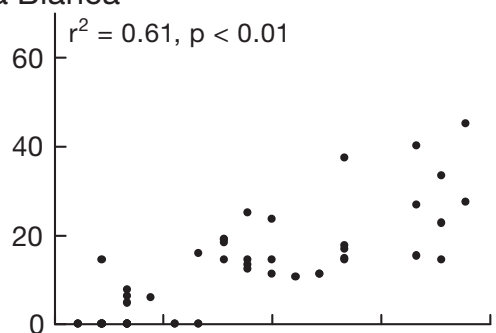

Bahía Anegada
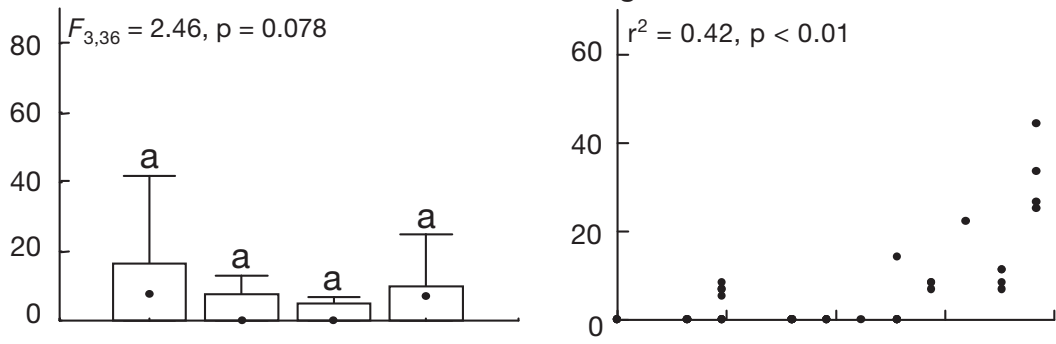

Bahía de San Antonio Oeste
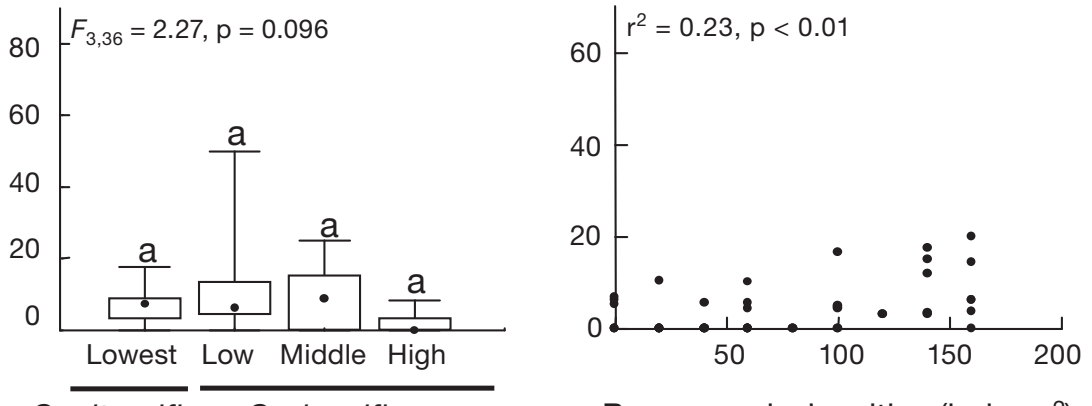

S. alterniflora S. densiflora

Burrow crab densities (ind. $\mathrm{m}^{-2}$ )

Fig. 3. Spartina spp. and Haimbachia sp. nov. across 5 southwestern Atlantic coastal marshes. (a) Proportion of stems of $S$. alterniflora and $S$. densiflora attacked by the moth at different marsh elevations. (b) Relationship between the proportion of stems of $S$. densiflora attacked by the moth, and crab densities in the low marsh (n = 50, see also Fig. 2). In this and subsequent figures: limits of the box: 25th and 75th percentiles, vertical lines: minima and maxima, black dot inside the box: median value. Different letters indicate differences $(p<0.05)$ by Tukey test after ANOVA; na: absence of plants at that marsh elevation 


\section{Does increased nutrient supply lead to an increase in herbivory pressure by stem borers?}

In both Spartina densiflora marshes (San Clemente and Mar Chiquita), nutrient addition resulted in a 3fold higher proportion of attacked stems (respectively: mean $\pm \mathrm{SD}=21.48 \pm 10.82 ; 5.57 \pm 3.91)$ than in control plots (respectively: $6.43 \pm 4.76, t_{12}=3.37, \mathrm{p}=0.0056$; $1.62 \pm 2.45, t_{16}=2.56, \mathrm{p}=0.0041$, Fig. 5).

\section{DISCUSSION}

Our results show that in several representative marshes of the SW Atlantic coastline, the moth Haimbachia sp. nov. is an important herbivore on Spartina spp. We also show that the positive effects of the crab Neohelice granulata on plants cascaded up, resulting in increased moth attack frequencies on $S$. densiflora. Thus, part of the positive effect of crabs on $S$. densiflora results in an indirect negative effect on the plants. Therefore, crabs, acting as ecosystem engineers, alter the energy flows between trophically interconnected organisms, leading to an increase in herbivore incidence.

Stem borers can be very common in marshes. In northwest Florida (USA) marshes, for example, at least $40 \%$ of the total available stem internodes of Spartina alterniflora can be perforated by larvae of different insect species (Stiling \& Strong 1983). In S. alterniflora collected along the Louisiana (USA) coast, $20 \%$ of the stems supported at least 1 larva, whereas an additional

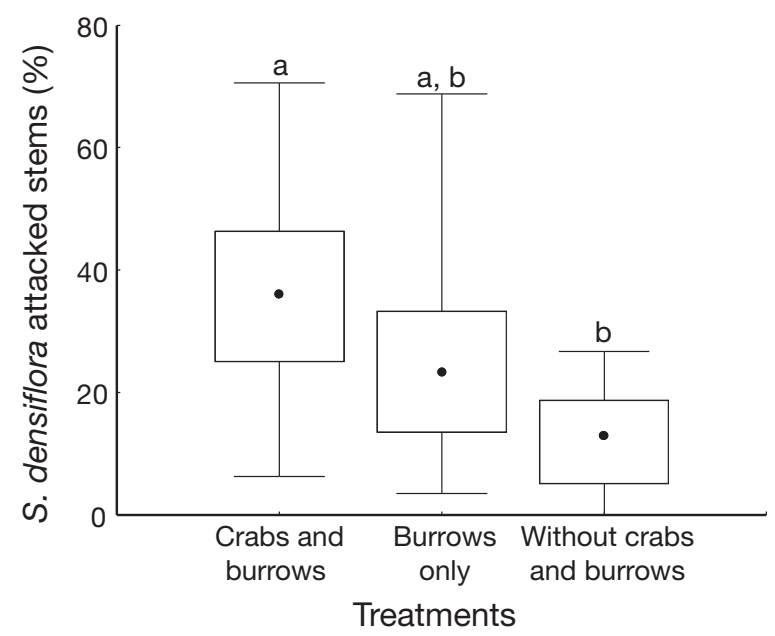

Fig. 4. Spartina densiflora and Haimbachia sp. nov. Proportion of $S$. densiflora stems attacked by the moth in experimental areas with Neohelice granulata and its burrows (crabs + burrows treatment), burrows-only treatment, and without N. granulata and its burrows (exclusion treatment). Different letters show differences by Tukey test after an ANOVA $(\mathrm{p}<0.05)$

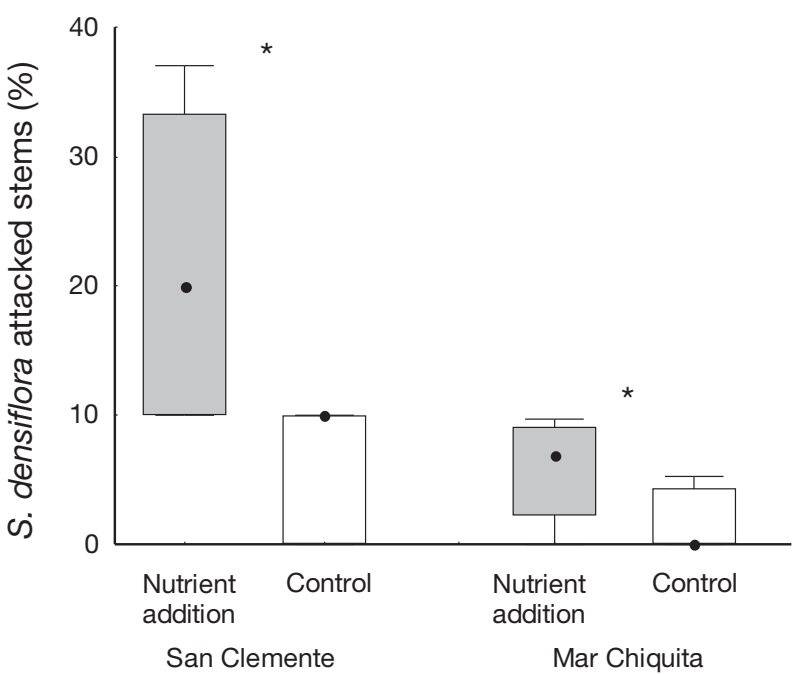

Fig. 5. Spartina densiflora and Haimbachia sp. nov. Effect of nutrient levels on the proportion of $S$. densiflora stems attacked by the moth in San Clemente and Mar Chiquita marshes. ${ }^{*}: \mathrm{p}<0.05$ (differences detected by $t$-test)

$17 \%$ exhibited evidence of prior insect feeding (White et al. 2005). Throughout SW Atlantic coastal marshes, Haimbachia sp. nov. attacked an important fraction of $S$. densiflora and $S$. alterniflora stems (from $4 \%$ to $26 \%$, depending on marsh elevation and site). Stem borers can have negative effects on marsh plants (e.g. Klopatek \& Stearns 1978). Indeed, our results show that by the end of the life cycle of the larvae (summer), at least half of the length of each attacked stem from which moths had not emerged yet (larvae or pupae) was dry, whereas all attacked stems from which moths had already emerged were completely dry. Given that across SW Atlantic coastal marshes Spartina spp. do not die in winter but grow all year (stems live for more that 1 yr, e.g. Vera et al. 2009), these observations suggest that feeding by moth larvae has an impact on the salt marsh community by increasing the availability of dry stems.

Our results also showed that in marshes with a high proportion of attacked stems, moth attack was more frequent on Spartina alterniflora than on S. densiflora (see Fig. 3). This pattern may be due to different plant palatability or moth preference (e.g. Goranson et al. 2004). However, this pattern could also result from differences in physical stress across the tidal gradient. $S$. alterniflora occurs at a lower elevation of the marsh than S. densiflora (Isacch et al. 2006). Indeed, the damage by moths on $S$. densiflora marshes was also higher in the low marsh compared to the high marsh. Plants that grow at higher tidal elevations are usually exposed to limiting hypersaline soil conditions as a result of pore water evaporation, and low nutrient availabil- 
ity, which can have profound impacts on salt marsh plant performance (Bertness et al. 1992, Emery et al. 2001, Goranson et al. 2004) and consumers (Moon \& Stiling 2000, 2002, Rand 2002). Thus, environmental factors might play an important role in mediating marsh plant-moth interactions.

Environmental conditions for plant growth are generally harsh in salt marshes (e.g. Pezeshki 2001). Ecosystem engineering by burrowing organisms usually changes the primary limiting resource, potentially having strong effects on the conditions in harsh habitats (e.g. Jones et al. 1997). For example, in alpine meadows, mounds from burrowing plateau zokors Myospalax baileyi enhance the biomass of adjacent plants (Wang et al. 2008). Also, in the arid Negev Desert Highlands of southern Israel, digging by the crested porcupine Hystrix indica enhances the growth of annual plants (Alkon 1999). In cool desert environments, the added moisture from spring recharge in ground squirrel Spermophilus townsendii burrows can increase plant productivity (Laundré 1998). Also in salt marshes of the east coast of North America, the burrowing activity of mud fiddler crab Uca pugnax (Bertness 1985) and the burrowing activity of Neohelice granulata in SW Atlantic coastal marshes increases the production of Spartina spp. (Daleo et al. 2007). The most likely mechanisms of enhanced Spartina spp. growth include that crab burrows increase sediment drainage and oxygen concentrations (Bertness 1985, Gutierrez et al. 2006, Daleo et al. 2007, Fanjul et al. 2008), which in turn may reduce phytotoxin concentrations (e.g. Smith et al. 1991), an effect that might be even more important in the highly anoxic low marsh. In addition, burrow structure may enhance nutrient availability, possibly because burrows act as detritus traps (Botto et al. 2006), and may also accumulate ammonium (Fanjul et al. 2008) from crab excretions and cached food (Bertness 1985, Fanjul et al. 2008, Kristensen 2008). Consequently, the positive effects of crab activities on plant productivity (Bertness 1985, Daleo et al. 2007) could indirectly facilitate primary consumers. Indeed, on the large scale of our sampled marshes, there is a positive relationship between crabs and moth spatial distribution. Overall, moths attacked more than $50 \%$ of $S$. densiflora stems in areas with high crab densities and less than $10 \%$ in areas with lower crab densities. Our experiment evaluating this pattern confirmed that this association was driven by crabs and not by an underlying factor affecting both species (moths and crabs). Plants growing in cages with crabs (and their burrows) had more than twice the proportion of attacked stems than plants in cages from which crabs (and their burrows) were excluded. The proportion of attacked stems in cages with burrows only (no crabs) showed intermediate values that did not differ from either of the other treatments. This intermediate attack frequency in stems from cages with only burrows could mean that the effect of burrowing crabs on moths is mediated by 2 mechanisms: (1) crab burrows (which can increase sediment drainage and oxygen concentrations and (2) crab activities which can increase nutrient availability from excretions and cached food, Kristensen 2008. Nutrient additions also increased moth attack frequencies, suggesting that crab effects on moth attacks may be driven by nutrient availability. As a consequence, the positive bottom-up effects of crabs on Spartina spp. improve their quality as a food resource and make these plants more susceptible to attacks by moths.

Thus, crabs have positive effects on plant growth mediated by ecosystem engineering processes (Daleo et al. 2007) that can cascade to upper trophic levels (Cardoni et al. 2007, Canepuccia et al. 2008, this study). However, crabs are also herbivores, and hence, they can have negative effects on plants (Bortolus \& Iribarne 1999, Costa et al. 2003, Bortolus et al. 2004, Alberti et al. 2007), particularly on plants of marsh-mudflat edges, or in isolated plants compared to those surrounded by neighbors (Alberti et al. 2007). The balance between those negative and positive effects by crabs upon plant growth is regulated by the physical characteristics of the local environment where interactions take place (Daleo \& Iribarne 2009). While crab presence increases sediment aeration and nutrient availability, these positive effects are most important in stressful zones (e.g. where oxygen availability is low, Daleo \& Iribarne 2009). However, in zones where the naturally high porosity allows better oxygenation, there can be an increase in the negative effects of crabs (Daleo \& Iribarne 2009). This might explain the weaker relationship between crab densities and moth attack frequencies in the 2 salt marshes located at the southern distribution of our study sites (and the lack of differences between marsh elevations). These marshes develop on larger grain size sediments than those located to the north (Daleo \& Iribarne 2009), which may increase the negative effect of crab herbivory.

Bottom-up and top-down forces act on plant production simultaneously, and the balance between the 2 ways of regulation depends on the environmental context. Studies have shown how top-down factors can increase together with the quality of the environment in a wide variety of harsh ecosystems (e.g. mountain, Prezler \& Boecklen 1996; goldenrod community, Uriarte \& Schmitz 1998; salt marshes, Bertness et al. 2008, Sala et al. 2008). In this context, our study shows how an ecosystem engineering crab positively affects plant productivity (e.g. Daleo et al. 2007), indirectly increasing top-down control by modulating herbivore inci- 
dence. Therefore, given that ecosystem engineers that ameliorate physical stress are a common component of harsh environments (see Wright \& Jones 2004, 2006), our work suggests the possibility that in these systems, biotic factors that increase plant performance will lead to an increase in herbivory control.

Acknowledgements. We thank M.A. Solis (Systematic Entomology Laboratory, Agricultural Research Service, US Department of Agriculture) for identifying the moth, and M.S. Fanjul, R. Jefferies, R. Osman, and 3 anonymous reviewers for their valuable suggestions and corrections on previous versions of this manuscript. This project was supported by grants from the Universidad Nacional de Mar del Plata, the Fundación Antorchas (Argentina, A013672 and 13900-13), CONICET, and ANPCyT (all to O.I.). J.A. and P.D. were supported by scholarship from CONICET (Argentina), and J.P. by a scholarship from CIC (Argentina).

\section{LITERATURE CITED}

Adam P (1993) Saltmarsh ecology. Cambridge studies in ecology. Cambridge University Press, Cambridge

Alberti J, Escapa M, Daleo P, Iribarne OO, Silliman B, Bertness M (2007) Local and geographic variation in grazing intensity by herbivorous crabs in SW Atlantic salt marshes. Mar Ecol Prog Ser 349:235-243

> Alkon PU (1999) Microhabitat to landscape impacts: crested porcupine digs in the Negev Desert highlands. J Arid Environ 41:183-202

Bertness MD (1985) Fiddler crab regulation of Spartina alterniflora production on a New England salt marsh. Ecology 66:1042-1055

Bertness MD, Gough L, Shumway SW (1992) Salt tolerances and the distribution of fugitive salt marsh plants. Ecology 73:1842-1851

Bertness MD, Crain C, Holdredge C, Sala N (2008) Eutrophication and consumer control of New England salt marsh primary productivity. Conserv Biol 22:131-139

Bortolus A, Iribarne OO (1999) Effect of the Southwestern Atlantic burrowing crab Chasmagnathus granulata on a Spartina salt marsh. Mar Ecol Prog Ser 178:79-88

Bortolus A, Laterra P, Iribarne OO (2004) Crab-mediated phenotypic changes in Spartina densiflora Brong. Estuar Coast Shelf Sci 59:97-107

Botto F, Valiela I, Iribarne OO, Martinetto P, Alberti J (2005) Impact of burrowing crabs on $\mathrm{C}$ and $\mathrm{N}$ sources, control, and transformations in sediments and food webs of SW Atlantic estuaries. Mar Ecol Prog Ser 293:155-164

Botto F, Iribarne OO, Gutierrez J, Bava J, Gagliardini A, Valiela I (2006) Ecological importance of passive deposition of organic matter into burrows of the SW Atlantic crab Chasmagnathus granulatus. Mar Ecol Prog Ser 312: 201-210

Canepuccia AD, Fanjul MS, Fanjul E, Botto F, Iribarne OO (2008) The intertidal burrowing crab Neohelice (= Chasmagnathus) granulata positively affects foraging of rodents in south western Atlantic salt marshes. Estuaries Coasts 31:920-930

> Cardoni DA, Isacch JP, Iribarne OO (2007) Indirect effects of the intertidal burrowing crab Chasmagnathus granulatus in the habitat use of Argentina's south west Atlantic saltmarsh birds. Estuaries Coasts 30:382-389
Costa CSB, Marangoni JC, Azevedo AMG (2003) Plant zonation in irregularly flooded salt marshes: relative importance of stress tolerance and biological interactions. J Ecol 91:951-965

Daleo P, Iribarne OO (2009) Beyond competition: the stress gradient hypothesis tested in plant-herbivore interactions. Ecology 90:2368-2374

Daleo P, Fanjul E, Mendez Casariego A, Silliman BR, Bertness MD, Iribarne OO (2007) Ecosystem engineers activate mycorrhizal mutualism in salt marshes. Ecol Lett 10: 902-908

Daleo P, Alberti J, Canepuccia AD, Escapa M and others (2008) Mycorrhizal fungi determine salt-marsh plant zonation depending on nutrient supply. J Ecol 96:431-437

Emery NC, Ewanchuk PJ, Bertness MD (2001) Competition and salt-marsh plant zonation: stress tolerators may be dominant competitors. Ecology 82:2471-2485

> Fanjul ME, Grela MA, Iribarne OO (2007) Effects of the dominant SW Atlantic intertidal burrowing crab Chasmagnathus granulatus on sediment chemistry and nutrient distribution. Mar Ecol Prog Ser 341:177-190

> Fanjul E, Grela MA, Canepuccia AD, Iribarne OO (2008) The Southwest Atlantic intertidal burrowing crab Neohelice granulata modifies nutrient loads of phreatic waters entering coastal area. Estuar Coast Shelf Sci 79:300-306

- Goranson CE, Ho CK, Pennings SC (2004) Environmental gradients and herbivore feeding preferences in coastal salt marshes. Oecologia 140:591-600

Gutierrez JLC, Jones CG, Groffman PM, Findlay SEG, Iribarne OO, Ribeiro PD, Bruschetti CM (2006) The contribution of crab burrow excavation to carbon availability in superficial saltmarsh sediments. Ecosystems 9:647-658

Iribarne OO, Bortolus A, Botto F (1997) Between-habitat differences in burrow characteristics and trophic modes in the southwestern Atlantic burrowing crab Chasmagnathus granulata. Mar Ecol Prog Ser 155:137-145

Isacch JP, Costa CSB, Rodríguez-Gallego L, Conde D, Escapa M, Gagliardini DA, Iribarne OO (2006) Distribution of salt marsh plant communities associated with environmental factors along a latitudinal gradient on the south-west Atlantic coast. J Biogeogr 33:888-900

Jefferies RL (1997) Long term damage of sub-arctic ecosystems by geese: ecological indicators and measures of ecosystem dysfunction. In: Crawford RMM (ed) Disturbance and recovery in arctic lands: an ecological perspective. Kluwer, Boston, MA, p 151-166

Jefferies RL, Jano AP, Abraham KF (2006) A biotic agent promotes large-scale catastrophic change in the coastal marshes of Hudson Bay. J Ecol 94:234-242

Jones CG, Lawton J, Shachak M (1994) Organisms as ecosystem engineers. Oikos 69:373-386

Jones CG, Lawton J, Shachak M (1997) Positive and negative effects of organisms as physical ecosystem engineers. Ecology 78:1946-1957

Klopatek JM, Stearns FW (1978) Primary productivity of emergent macrophytes in a Wisconsin freshwater marsh ecosystem. Am Midl Nat 100:320-332

Kristensen E (2008) Mangrove crabs as ecosystem engineers; with emphasis on sediment processes. J Sea Res 59:30-43

Laundré JW (1998) Effect of ground squirrel burrows on plant productivity in a cool desert environment. J Range Manag 51:638-643

> Mayhew PJ (1997) Adaptive patterns of host plant selection by phytophagous insects. Oikos 79:417-428

Menge B, Sutherland J (1976) Species diversity gradients: synthesis of the roles of predation, competition, and temporal heterogeneity. Am Nat 110:351-369 
Mitsch WJ, Gosselink JG (2001) Wetlands. Van Nostrand Reinhold, New York, NY

Moon DC, Stiling P (2000) Relative importance of abiotically induced direct and indirect effects on a salt marsh herbivore. Ecology 81:470-481

Moon DC, Stiling P (2002) The effects of salinity and nutrients on a tritrophic salt marsh system. Ecology 83:2465-2476

Moravie MA, Borer M, Bacher S (2006) Neighbourhood of host plants influences oviposition decisions of a stemboring weevil. Basic Appl Ecol 7:545-554

Odum EP, Smalley AE (1959) Comparison of population energy flow of a herbivorous and a deposit-feeding invertebrate in a salt marsh ecosystem. Proc Natl Acad Sci USA 45:617-622

Pezeshki SR (2001) Wetland plant responses to soil flooding. Environ Exp Bot 46:299-312

Power ME (1992) Top-down and bottom-up forces in food webs: Do plants have primacy? Ecology 73:733-746

Prezler RW, Boecklen WJ (1996) The influence of elevation on tri-trophic interactions: opposing gradients of top-down and bottom-up effects on a leaf-mining moth. Ecoscience 3:75-80

Rand TA (2002) Variation in insect herbivory across a salt marsh tidal gradient influences plant survival and distribution. Oecologia 132:549-558

Rathcke BJ (1976) Competition and coexistence within a guild of herbivorous insects. Ecology 57:76-87

Sakai K, Türkay M, Yang SL (2006) Revision of the Helice/ Chasmagnathus complex (Crustacea: Decapoda: Brachyura). Abh Senckenb Naturforsch Ges 565:1-76

Sala NM, Bertness MD, Silliman BR (2008) The dynamics of bottom-up and top-down control in a New England salt marsh. Oikos 117:1050-1056

Silliman BR, Zieman JC (2001) Top-down control of Spartina alterniflora production by periwinkle grazing in a Virginia salt marsh. Ecology 82:2830-2845

Smith TJ III, Boto KG, Frusher SD, Giddins RL (1991) Keystone species and mangrove forest dynamics: the influence of burrowing by crabs on soil nutrient status and forest productivity. Estuar Coast Shelf Sci 33:419-432

Spivak E, Anger K, Luppi T, Bas C, Ismael D (1994) Distribution and habitat preferences of two grapsid crab species in Mar Chiquita Lagoon (Province of Buenos Aires,

Editorial responsibility: Richard Osman,

Edgewater, Maryland, USA
Argentina). Helgol Meeresunters 48:59-78

Stiling PD, Strong DR (1983) Weak competition among Spartina stem borers, by means of murder. Ecology 64 : 770-778

Stiling PD, Strong DR (1984) Experimental density manipulation of stem-boring insects: some evidence for interspecific competition. Ecology 65:1683-1685

Strong DR (1992) Are trophic cascades all wet? Differentiation and donor-control in speciose systems. Ecology 73:747-754

Teal JM (1962) Energy flow in the salt marsh ecosystem of Georgia. Ecology 43:614-624

Uriarte M, Schmitz OJ (1998) Trophic control across a natural productivity gradient with sap-feeding herbivores. Oikos 82:552-560

Valiela I, Teal JM (1974) Nutrient limitation of salt marsh vegetation. In: Reimold RJ, Queen WH (eds) Ecology of halophytes. Academic Press, New York, NY, p 547-563

> Valiela I, Tomasky G, Hauxwell J, Cole M, Cebrian J, Kroeger K (2000) Operationalizing sustainability: management and risk assessment of land-derived nitrogen loads to shallow estuaries. Ecol Appl 10:1006-1023

> Vera F, Gutierrez JL, Ribeiro PD (2009) Aerial and detritus production of the cordgrass Spartina densiflora in a southwestern Atlantic salt marsh. Botany 87:482-491

> Walker M, Jones TH (2001) Relative roles of top-down and bottom-up forces in terrestrial tritrophic plant-insect herbivore-natural enemy systems. Oikos 93:177-187

Wang TC, Xiong YC, Ge JP, Wang SM and others (2008) Four-year dynamic of vegetation on mounds created by zokors (Myospalax baileyi) in a subalpine meadow of the Qinghai-Tibet Plateau. J Arid Environ 72:84-96

> White WH, Adamski D, Fine G, Richard EP Jr (2005) Stemborers associated with smooth cord grass, Spartina alterniflora (Poaceae), in a nursery habitat. Fla Entomol 88: 390-394

> Wright JP, Jones CG (2004) Predicting effects of ecosystem engineers on patch-scale species richness from primary productivity. Ecology 85:2071-2081

> Wright JP, Jones CG (2006) The concept of organisms as ecosystem engineers ten years on: progress, limitations, and challenges. Bioscience 56:203-209

Zar JH (1999) Biostatistical analysis, 3rd edn. Prentice-Hall, Englewood Cliffs, NJ

Submitted: September 16, 2009; Accepted: January 20, 2010 Proofs received from author(s): March 31, 2010 